\title{
Effects of an extract of Celtis aetnensis (Tornab.) Strobl twigs on human colon cancer cell cultures
}

\author{
ROSARIA ACQUAVIVA ${ }^{1}$, VALERIA SORRENTI ${ }^{1}$, ROSA SANTANGELO ${ }^{1}$, VENERA CARDILE ${ }^{2}$, \\ BARBARA TOMASELLO ${ }^{1}$, GIUSEPPE MALFA ${ }^{1}$, LUCA VANELLA $^{1}$, ANDREA AMODEO $^{3}$, CARLO GENOVESE $^{3}$, \\ SILVANA MASTROJENI ${ }^{3}$, MICHELA PUGLIESE ${ }^{4}$, MONICA RAGUSA $^{4}$ and CLAUDIA DI GIACOMO ${ }^{1}$ \\ ${ }^{1}$ Department of Drug Science, Biochemistry Section, ${ }^{2}$ Department of Bio-medical Sciences, Physiology Section, and \\ ${ }^{3}$ Department of Bio-medical Sciences, Microbiology Section, University of Catania, I-95123 Catania; \\ ${ }^{4}$ Department of Veterinary Sciences, University of Messina, Polo Universitario dell'Annunziata, I-98168 Messina, Italy
}

Received December 1, 2015; Accepted January 8, 2016

DOI: 10.3892/or.2016.5035

\begin{abstract}
Cancers of the digestive tract, in particular colorectal cancer (CRC), are among those most responsive to dietary modification. Research has shown that approximately $75 \%$ of all sporadic cases of CRC are directly influenced by diet. Many natural compounds have been investigated for their potential usefulness as cancer chemopreventive agents as they have been thought to suppress carcinogenesis mainly during the initiation phase due to their radical scavenger activity. Since there is an increasing interest in the in vivo protective effects of natural compounds contained in plants against oxidative damage involved in several human diseases such as cancer, the aim of the present research was to test the effects of a Celtis aetnensis (Tornab.) Strobl twig extract on a human colon carcinoma cell line (Caco2). In order to elucidate the mechanisms of action of this extract, LDH release, GSH content, ROS levels, caspase- 3 and $\gamma$-GCS expression were also evaluated. The results revealed that the Celtis aetnensis extract reduced the cell viability of the Caco 2 cells inducing apoptosis at the lowest concentration and necrosis at higher dosages. In addition, this extract caused an increase in the levels of ROS, a decrease in RSH levels and in the expression of HO-1. The expression of $\gamma$-GCS was not modified in the Celtis aetnensis-treated Caco-2 cells. These results suggest an interference of this extract on the oxidant/antioxidant
\end{abstract}

Correspondence to: Professor Claudia Di Giacomo, Department of Drug Science, Biochemistry Section, University of Catania, Viale Andrea Doria 6, I-95123 Catania, Italy

E-mail: cdigiaco@unict.it

In Memoriam: This work is dedicated to the memory of Professor Liliana Iauk.

Key words: colorectal cancer, oxidative stress, Celtis aetnensis, heme oxygenase-1, $\gamma$-glutamylcysteine synthetase cell balance with consequent cell damage. The present study supports the growing body of data suggesting the bioactivities of Celtis aetnensis (Tornab.) Strobl and its potential impact on cancer therapy and on human health.

\section{Introduction}

Colorectal cancer is the third most common malignancy in males and the second most common in females, with significant variations in the worldwide distribution. In veterinary medicine it was described in sheep and dog with a different incidence (1). A more than 10-fold variation in the colorectal cancer incidence rate across countries and the rapid increase in incidence rates in countries experiencing industrialization suggest a strong link with lifestyle factors. The highest incidence rates are found in economically developed countries, whereas the lowest rates are noted in Africa and South-Central Asia (2). However, recent 'perturbations' in colorectal cancer incidence trends were observed probably resulting from a combination of risk factors, including obesity, sedentary lifestyle, increased prevalence of smoking, excessive alcohol consumption and 'westernization' in dietary habits - a diet rich in red and processed meat and low intake of fruits and vegetables $(3,4)$.

The possibility that fruit and vegetables may help to reduce the risk for various types of cancer raised great interest already in the 1970s, when studies conducted to assess differences in cancer rates and diet between countries, suggested that various dietary factors may have important effects on cancer risk $(5,6)$. Several years later, a joint report by the World Cancer Research Fund together with the American Institute of Cancer Research found 'convincing' evidence that a high fruit and vegetable intake would reduce cancer of the colon and rectum $(4,7)$.

It is known that plants may be used both as a medicine and a food and it is difficult to draw a line between these two groups: food may be medicine, and vice versa. In traditional societies, plants are often used multi-contextually, for example, as food and for medicine (8). Particularly interesting are the pharmacological properties of these plants and of the constituents isolated from them. 
Epidemiologic studies suggest that the consumption of natural compounds lowers the risk of cardiovascular disease, diabetes, arthritis and cancer $(4,9)$.

The genus Celtis (Ulmaceae) includes about 70 species of shrubs or trees, primarily distributed in the temperate and tropical regions of the Northern Hemisphere (10). Celtis aetnensis (Tornab.) Strobl is a bushy shrub present on Mount Etna (Sicily) (11). It is a woody plant, whose leaves are heart-shaped and slightly crenate on the edge. Some species of Celtis are used in traditional medicine for the treatment of low back pain, upset stomach, abdominal pain, as well as for their astringent and soothing in case of diarrhea, enteritis and inflammation of the oral cavity. These properties are primarily attributable to the active principles contained in the leaves, such as tannins, saponins and flavonoids.

In previous phytochemical reports on species of the genus Celtis, the presence of betulin, gallic acid, 3,3'-di-O-methylellagic acid, moretenol and two triterpene esters, $3 \beta$-transsinapoyloxylup-20(29)-en-28-ol and 3 $\beta$-trans-feruloyloxy16 $\beta$-hydroxylup-20(29)-ene and five known triterpenes, $3 \beta-O-(E)$-feruloylbetulin, 3 $\beta$-O-(E)-coumaroylbetulin, betulin, 20-epibryonolic acid, and ursolic acid, were isolated from the twigs of $C$. philippinensis $(10,12)$.

Antioxidant and cytotoxic activities were reported for other Celtis species e.g., Celtis philippinensis Blanco, Celtis africana Burm. f., and Celtis iguanae (Jacq.) Sarg. (10,13-16), however, as far as we know, no previous biological and phytochemical investigations on Celtis aetnensis (Tornab.) Strobl have been reported.

Many antioxidant compounds have been investigated for their potential usefulness as cancer chemopreventive agents (17-19). Since there is an increasing interest in the in vivo protective effects of natural compounds contained in plants against oxidative damage involved in several human diseases such as cancer, the present study investigated the effects of Celtis aetnensis (Tornab.) Strobl twig extract on the viability of the human carcinoma $\mathrm{Caco} 2$ cell line. In addition, in order to elucidate the mechanisms of action of this extract, LDH release, caspase expression, thiol groups, ROS levels, HO-1 and $\gamma$-GCS protein expression were also evaluated.

\section{Materials and methods}

Chemicals. 3-(4,5-Dimethylthiazol-2-yl)2,5-diphenyltetrazolium bromide (MTT) and 2',7'-dichlorofluorescein diacetate (DCFH-DA) were obtained from Sigma Aldrich Co. (St. Louis, MO, USA). All other chemicals were purchased from Gibco-BRL Life Technologies (Grand Island, NY, USA). Polyclonal $\gamma$-glutamylcysteine synthetase $(\gamma$-GCS) and caspase antibodies were from Abcam (Victoria, BC,Canada). Secondary horseradish peroxidase-conjugated anti-rabbit antibodies were from Santa Cruz Biotechnology (Santa Cruz, CA, USA). The enhanced chemiluminescence system for developing immunoblots and nitrocellulose membranes was purchased from Amersham (Milano, Italy). The ELISA kit, used to measure heme oxygenase-1 (HO-1) protein concentration, was from Stressgen Biotechnologies (Victoria, BC, Canada).

Plant material and preparation of the extract. Twigs of Celtis aetnensis (Tornab.) Strobl (Ulmaceae) were collected in the area around Linguaglossa (Catania, Italy) in June 2015. The specimens were obtained thanks to the Regional Forest Corps Detachment of Catania-Nicolosi and authenticated by botanist Professor S. Ragusa, Department of Health Sciences, University of Catanzaro (Italy). A voucher specimen of the plant was deposited in the herbarium of the same department.

Twigs of Celtis aetnensis (Tornab.) Strobl were air dried for 10 days, and then washed free from soil, powdered and stored in airtight containers at room temperature until extraction. One fraction of $50 \mathrm{~g}$ of the powdered twigs was exhaustively extracted by maceration with $\mathrm{MeOH}$ (w/v ratio of 1:5) at room temperature for $48 \mathrm{~h}$. The filtrate was dried under vacuum using a rotary evaporator, and the residue that dissolved in water was extracted with hexane. The aqueous solution was further extracted with chloroform. Finally the chloroform solution was brought to dryness (residual weight $133.6 \mathrm{mg}$ ).

Cell culture and treatments. Human colon carcinoma cells (Caco2), obtained from the American Type Culture Collection (ATCC; Rockville, MD, USA), were cultured in Dulbecco's modified essential medium (Gibco-BRL Life Technologies) supplemented with $10 \%$ foetal calf serum, $1 \mathrm{mmol} / 1$ sodium pyruvate, $2 \mathrm{mmol} / \mathrm{l} \mathrm{L-glutamine,} \mathrm{streptomycin}(50 \mathrm{mg} / \mathrm{ml})$ and penicillin $(50 \mathrm{U} / \mathrm{ml})$.

The cells were plated at a constant density to obtain identical experimental conditions in the different tests, thus to achieve a high accuracy of the measurements. After a 24-h incubation at $37^{\circ} \mathrm{C}$ under a humidified $5 \%$ carbon dioxide atmosphere to allow cell attachment, the cells were treated with different concentrations of the chloroformic extract of twigs from Celtis aetnensis (Tornab.) Strobl (5, 50, 100, 250 or $500 \mu \mathrm{g} / \mathrm{ml}$ ), and incubated for $72 \mathrm{~h}$ under the same conditions. Chloroformic extract was dissolved in dimethyl sulfoxide (DMSO) and diluited with medium to give final concentrations of total extract ranging from 5 to $500 \mu \mathrm{g} / \mathrm{ml}$. Four replicates were performed for each sample.

At the end of the treatment, the cells were scraped, washed with PBS and immediately utilized for analysis.

MTT bioassay. MTT assay was performed to monitor cell viability, measuring the conversion of tetrazolium salt to yield colored formazan, the amount of which is proportional to the number of living cells. For this assay, the cells were set up $\left(8 \times 10^{3}\right.$ cells/well) in a 96-multiwell flat-bottomed $200 \mu 1$ microplate (20). The optical density of each well was measured with a microplate spectrophotometer reader (Titertek Multiskan; Flow Laboratories, Helsinki, Finland) at $\lambda=570 \mathrm{~nm}$.

Lactic dehydrogenase release. Lactic dehydrogenase (LDH) release was measured to evaluate cell necrosis as a result of cell membrane disruption. LDH activity was measured spectrophotometrically in the culture medium and in the cellular lysates, at $\lambda=340 \mathrm{~nm}$ by analyzing NADH reduction (21). The percentage of $\mathrm{LDH}$ release was calculated as the percentage of the total amount, considered as the sum of the enzymatic activity present in the cellular lysate and that in the culture medium.

Thiol group determination. Thiol groups (RSH) were measured using a spectrophotometric assay as previously described (22). 


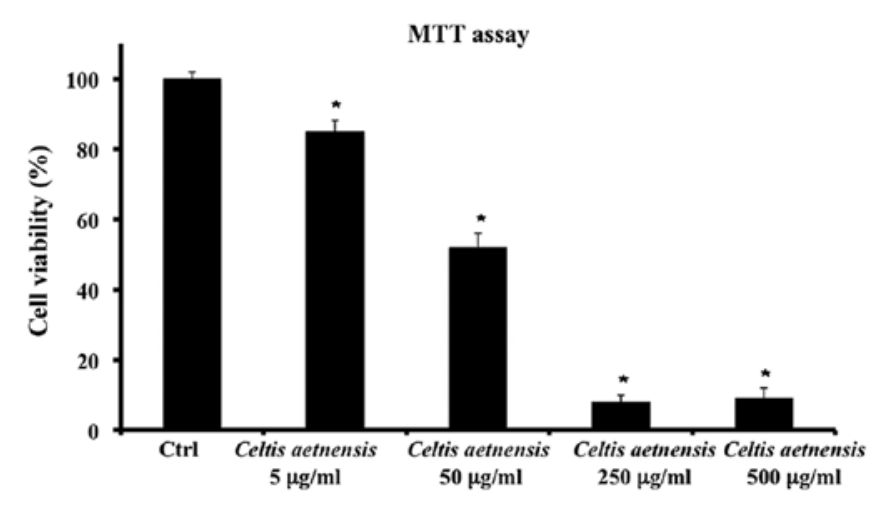

Figure 1. Cell viability in the Caco2 cells untreated and treated for $72 \mathrm{~h}$ with a chloroformic extract of Celtis aetnensis (Tornab.) Strobl at different concentrations $(5-500 \mu \mathrm{g} / \mathrm{ml})$. Values are the mean \pm SD of four experiments in triplicate. Significant vs. untreated control cells, ${ }^{*} \mathrm{P}<0.001$.

Results are expressed as $\mu \mathrm{mol} / \mathrm{mg}$ protein. Protein concentration was measured according to Bradford (23).

Reactive oxygen species assay. Determination of reactive oxygen species (ROS) was performed using a fluorescent probe 2',7'-dichlorofluorescein diacetate (DCFH-DA), as previously described (24). The fluorescence (corresponding to the oxidized radical species 2',7'-dichlorofluorescein, DCF) was monitored spectrofluorometrically (excitation, $\lambda=488 \mathrm{~nm}$; emission, $\lambda=525 \mathrm{~nm}$ ). The total protein content was evaluated for each sample, and the results are reported as the percentage increase in fluorescence intensity/mg protein with respect to the control (untreated) cells.

HO-1 protein expression. A commercially available enzyme-linked immunosorbent assay (ELISA) kit was used to measure HO-1 protein concentration in the cellular lysates. The assay was performed in accordance with the protocol provided by the manufacturer. Absorbance at $\lambda=450 \mathrm{~nm}$ was measured and HO-1 concentration was calculated from a standard curve generated with purified HO-1 (25). The limits of detection provided by the manufacturer were $0.78-25 \mathrm{ng} / \mathrm{ml}$. Results are expressed as ng/mg protein.

Western blottings. Caco2 cells were harvested using cell lysis buffer. The lysate was collected for western blot analysis and protein levels were visualized by immunoblotting with antibodies against $\gamma$-GCS and caspase-3 as previously described (21).

Statistical analysis. One-way analysis of variance (ANOVA) followed by Bonferroni's t-test was performed in order to estimate significant differences among groups. Data are reported as mean values $\pm \mathrm{SD}$, and differences between groups were considered to be significant at $\mathrm{P}<0.005$.

\section{Results}

Effects of Celtis aetnensis (Tornab.) Strobl on Caco2 cell viability. The treatment of Caco 2 cells with 5, 50, 250 or $500 \mu \mathrm{g} / \mathrm{ml}$ of chloroformic extract of Celtis aetnensis (Tornab.)

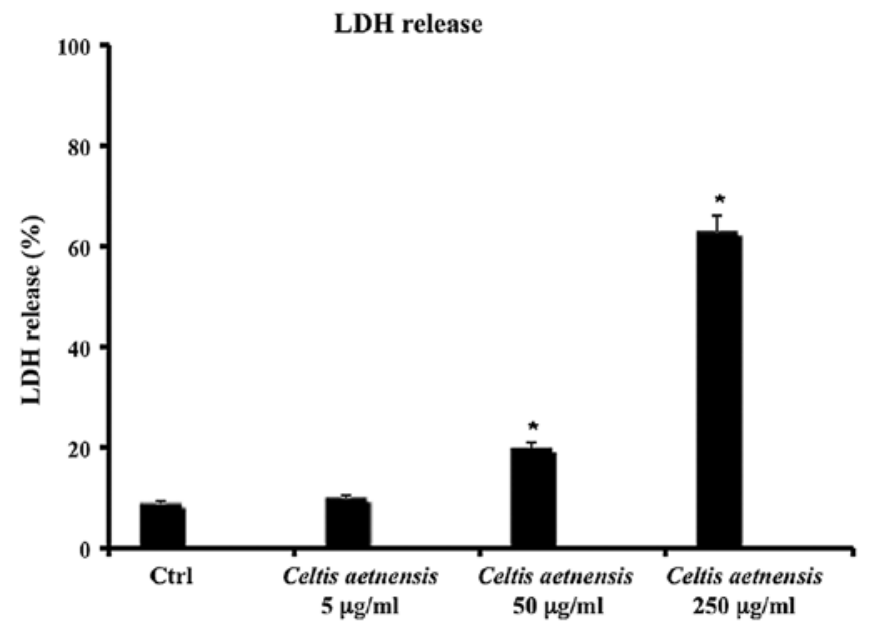

Figure 2. LDH released in the Caco 2 cells untreated and treated for $72 \mathrm{~h}$ with a chloroformic extract of Celtis aetnensis (Tornab.) Strobl at different concentrations $(5-250 \mu \mathrm{g} / \mathrm{ml})$. Values are the mean $\pm \mathrm{SD}$ of four experiments in triplicate. Significant vs. untreated control cells, ${ }^{*} \mathrm{P}<0.001$.

Strobl for $72 \mathrm{~h}$ resulted in a significant and dose-dependent reduction in cell viability (Fig. 1); since 250 and $500 \mu \mathrm{g} / \mathrm{ml}$ of chloroformic extract showed similar effects in other experiments we used $250 \mu \mathrm{g} / \mathrm{ml}$ of the extract.

$L D H$ release. Necrosis results in distruption of the cytoplasmic membrane with release of cytoplasmic LDH and other cytotoxic substances by necrotic cells into the medium. Thus, the existence of LDH in culture medium represents an indirect index of the membrane permeability of the treated cells. As shown in Fig. 2, $72 \mathrm{~h}$ of incubation with a chloroformic extract of Celtis aetnensis (Tornab.) Strobl $(5 \mu \mathrm{g} / \mathrm{ml})$ did not cause $\mathrm{LDH}$ release, while a statistically significant increase in $\mathrm{LDH}$ release was observed in the $\mathrm{Caco} 2$ cells treated with 50 and $250 \mu \mathrm{g} / \mathrm{ml}$ of extract (Fig. 2).

Caspase determination. Western blot analysis of caspase- 3 is considered a good marker of apoptosis. As shown in Fig. 3, the treatment of Caco 2 cells with a chloroformic extract of Celtis aetnensis (Tornab) Strobl (5-50-250 $\mu \mathrm{g} / \mathrm{ml})$ induced apoptotic cell death. This effect was also evident at the lowest dosage $(5 \mu \mathrm{g} / \mathrm{ml})$.

ROS assay. ROS are believed to be involved in cell death induced by a variety of stimuli and various antitumoral agents. In order to test the hypothesis that chloroformic extract-induced cell death may be mediated by an elevation in ROS levels, a fluorescent probe, DCFH-DA was used for ROS determination. This probe diffuses into the cells, intracellular esterases hydrolyze the acetate groups and the resulting DCFH then reacts with intracellular oxidants resulting in the observed fluorescence.

The intensity of fluorescence (FI) is proportional to the levels of intracellular oxidant species. As shown in Fig. 4, the addition of the chloroformic extract of Celtis aetnensis (Tornab.) Strobl at 5, 50 and $250 \mu \mathrm{g} / \mathrm{ml}$ for $72 \mathrm{~h}$ caused a significant increase in FI with respect to the untreated $\mathrm{Caco} 2$ cells. 


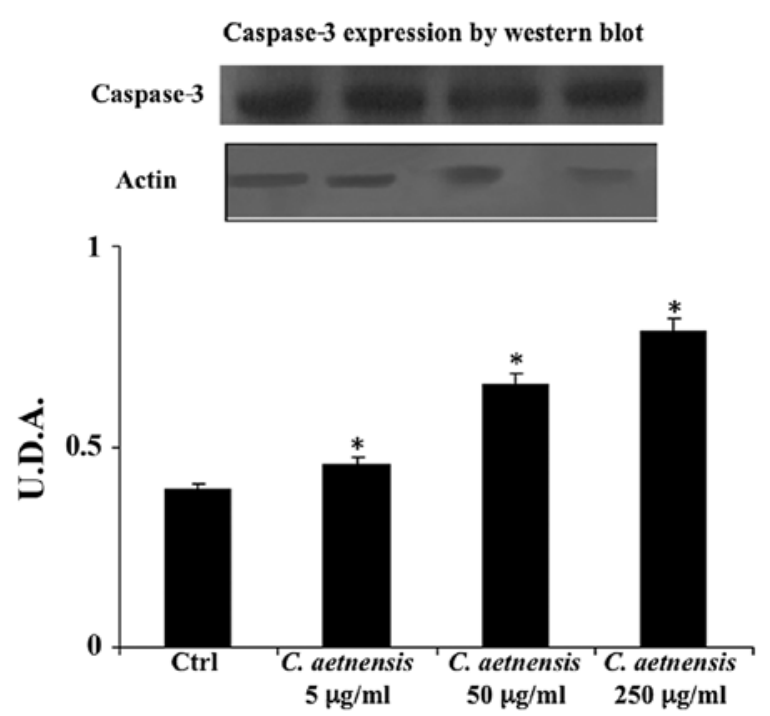

Figure 3. Immunoblotting of caspase-3 levels in the Caco2 cells untreated and treated for $72 \mathrm{~h}$ with a chloroformic extract of Celtis aetnensis (Tornab.) Strobl at different concentrations $(5-250 \mu \mathrm{g} / \mathrm{ml})$. Values are expressed as densitometric units corresponding to signal intensity present on autoradiographs. Values are the mean \pm SD of four experiments performed in triplicate. Significant vs. untreated control cells, ${ }^{*} \mathrm{P}<0.001$.

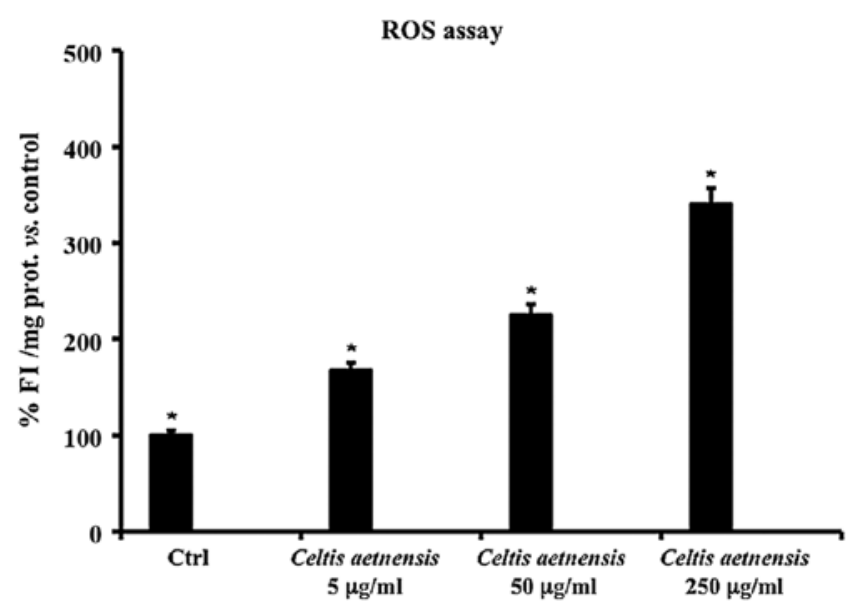

Figure 4. Intracellular oxidants in the Caco2 cells untreated and treated for $72 \mathrm{~h}$ with a chloroformic extract of Celtis aetnensis (Tornab.) Strobl at different concentrations $(5-250 \mu \mathrm{g} / \mathrm{ml})$. Values are the mean \pm SD of four experiments in triplicate. Significant vs. untreated control cells, ${ }^{*} \mathrm{P}<0.001$.

Thiol groups. In order to further confirm the involvement of radical/oxidative species in the action mechanism of chloroformic extract of Celtis aetnensis (Tornab.) Strobl, thiol group levels (RSH) were measured in the Caco2 cells. The treatment of these cells with $50-250 \mu \mathrm{g} / \mathrm{ml}$ of the chloroformic extract of Celtis aetnensis (Tornab.) Strobl resulted in a significant reduction in the levels of RSH (Fig. 5); the lowest concentration of the chloroformic extract of Celtis aetnensis (Tornab.) Strobl did not alter the levels of thiol groups RSH with respect to the control.

HO-1 by ELISA. Fig. 6 shows that the addition of 5, 50 and $250 \mu \mathrm{g} / \mathrm{ml}$ of the extract to Caco2 cells, resulted in a significant

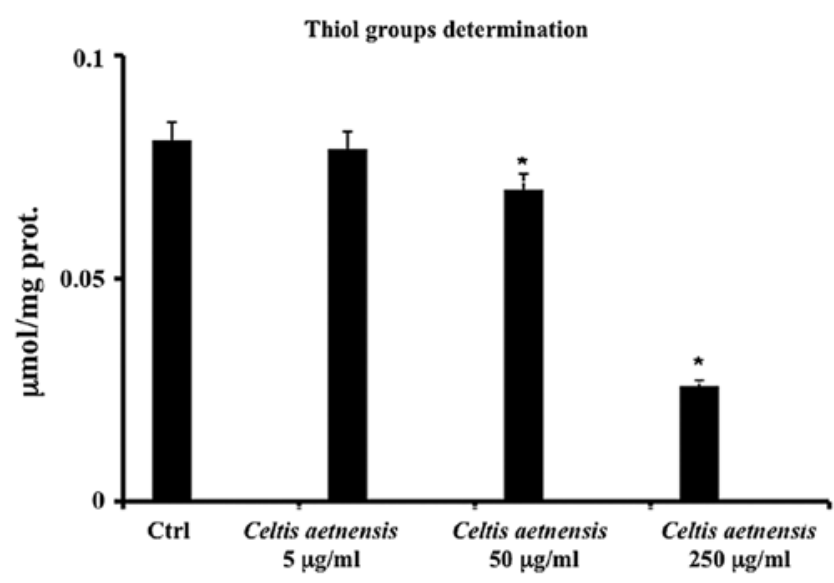

Figure 5. Thiol groups in the Caco2 cells untreated and treated for $72 \mathrm{~h}$ with a chloroformic extract of Celtis aetnensis (Tornab.) Strobl at different concentrations $(5-250 \mu \mathrm{g} / \mathrm{ml})$. Thiol groups are expressed as $\mu \mathrm{mol} / \mathrm{mg}$ protein. Values are the mean \pm SD of four experiments in triplicate. Significant vs. untreated control cells, ${ }^{*} \mathrm{P}<0.001$.

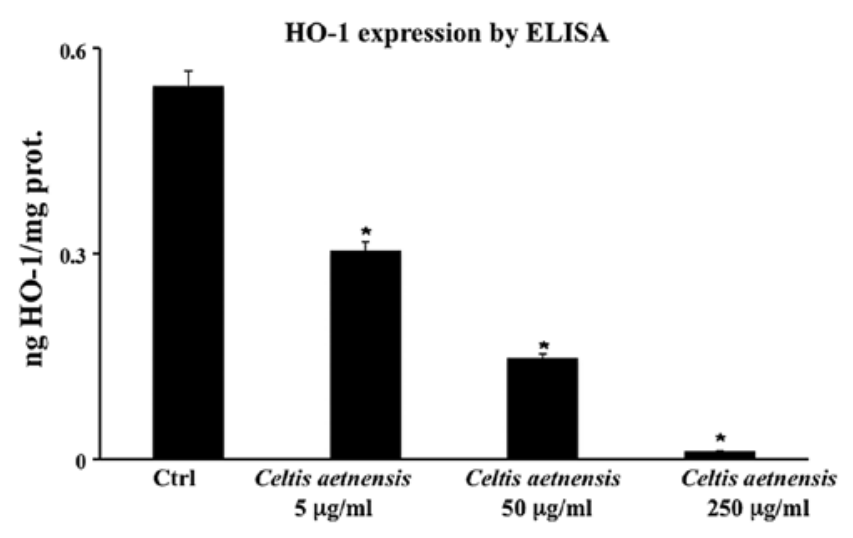

Figure 6. HO-1 levels in the Caco2 cells untreated and treated for $72 \mathrm{~h}$ with a chloroformic extract of Celtis aetnensis (Tornab.) Strobl at different concentrations $(5-250 \mu \mathrm{g} / \mathrm{ml})$. Results are expressed as $\mathrm{ng} / \mathrm{mg}$ proteins. Values are the mean \pm SD of four experiments in triplicate. Significant vs. untreated control cells, ${ }^{*} \mathrm{P}<0.001$

decrease in HO-1 protein expression which was undetectable at the highest concentration of the extract (Fig. 6).

$\gamma$-GCS determination. No significant change in $\gamma$-GCS expression was observed in the Caco2 cells treated with the extract of Celtis aetnensis (Tornab.) Strobl with respect to the untreated cells (Fig. 7).

\section{Discussion}

Cancer, a malignant tumor or a neoplasm, is a generic term for a broad group of diseases that can affect any part of the body via failure of regulation of cell mitosis. The processes of cancer development are i) rapid and abnormal cell division and growth, ii) formation of malignant tumors, iii) invasion to nearby adjoining parts of the body, and iv) spread to other organs through the lymphatic system and/or bloodstream. Cancer remains one of the most threatening diseases worldwide affecting human health and quality of life in spite of 


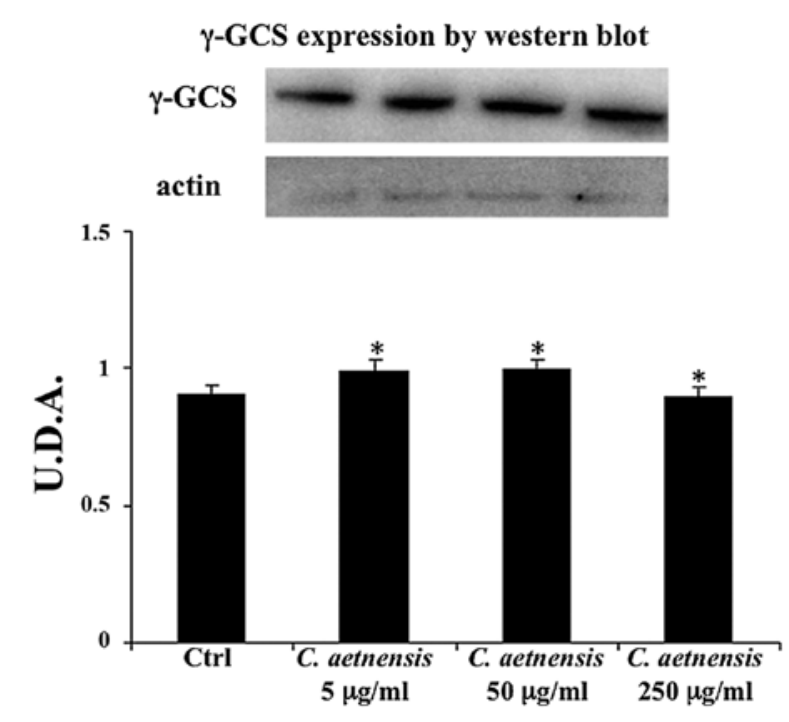

Figure 7. Immunoblotting of $\gamma$-GCS levels in the Caco 2 cells untreated and treated for $72 \mathrm{~h}$ with a chloroformic extract of Celtis aetnensis (Tornab.) Strobl at different concentrations $(5-250 \mu \mathrm{g} / \mathrm{ml})$. Values are expressed as densitometric units corresponding to signal intensity present on autoradiographs Values are the mean \pm SD of four experiments performed in triplicate Significant vs. untreated control cells, ${ }^{*} \mathrm{P}<0.001$.

the many recent advances in the knowledge of its molecular biology of induction and progression.

Cancer cells differ from normal cells due to the following properties: unlimited replication potential, absence of apoptosis, absence of telomere shortening, angiogenesis and metastasis. Colorectal carcinogenesis is related to the progressive loss of homeostatic control of cell proliferation, differentiation and apoptosis $(26,27)$. The human body exerts protective effects against tumor development mainly through apoptosis, cell cycle arrest and immune responses. Apoptosis, also known as programmed cell death, involves cell blebbing, shrinkage, nuclear fragmentation, chromatin condensation and chromosomal DNA fragmentation. It can be triggered by the activation of tumor-suppressor genes, caspases, apoptosis-inducing factors, cytotoxic T cells and natural killer (NK) cells via a Fas ligand- or perforin/granzyme B-dependent pathway $(28,29)$.

Natural compounds have been shown to affect molecular events involved in the initiation, promotion and progression of cancer, thereby inhibiting carcinogenesis. Furthermore, their inhibitory activity may ultimately suppress the final steps of carcinogenesis as well angiogenesis and metastasis.

Previous studies on ethnomedicine, together with extensive laboratory findings, indicate that flavonoids and triterpenic compounds play important roles in the prevention and treatment of cancer (10,30-33). Because of their safety, low toxicity and general acceptance as dietary supplements, fruits, vegetables, and other dietary elements (phytochemicals and minerals) are being investigated for the prevention of cancer. Extensive research over the past several decades has identified numerous dietary and botanical natural compounds with chemopreventive potential.

A number of reports have highlighted the important role of pro-oxidants and/or antioxidants by natural and synthetic compounds in chemo-prevention for many cancers $(34,35)$. Antioxidants have been thought to mainly suppress carcinogenesis during the initiation phase, since most act as radical scavengers, or inducers or inhibitors of xenobiotic metabolizing enzymes including phase I and II enzymes (36). In addition, some radical scavengers may also have pro-oxidative potential because of their conversion to more reactive or stable radicals after reaction with ROS.

There is a growing interest in flavonoids and triterpene esters and their synthetic derivatives due to their possible applications in cancer chemotherapy as anticancer and anti-inflammatory agents (37). Recently, it has been reported that a chloroformic extract of $C$.philippinensis twigs exhibited cytotoxic activity against the KB (human oral epidermoid carcinoma) cell line (10).

According to these findings, the results obtained in the present study showed that a chloroformic extract of Celtis aetnensis (Tornab.) Strobl significantly reduced the cell viability of Caco-2 cells and induced apoptotic and/or necrotic cell death in a concentration-dependent manner (Fig. 1). In particular, a chloroformic extract of Celtis aetnensis (Tornab.) Strobl induced apoptosis at the lowest concentration $(5 \mu \mathrm{M})$, while higher dosages $(50-250 \mu \mathrm{g} / \mathrm{ml})$ were able to increase LDH release, a marker of necrotic death (Figs. 2 and 3). Here, the reported data regarding the MTT assay, LDH release and caspase expression suggest that the chloroformic extract of Celtis aetnensis (Tornab.) Strobl penetrated the cancer cells with consequent apoptosis and or necrosis depending on the concentration.

The involvement of ROS in necrotic/apoptotic cell death induced by different agents, such as oxidants, toxicants or drugs, has been suggested (38). It is interesting to note that many human cancer cell types exist in a highly oxidative state due to decreased antioxidant protective enzyme levels compared to their normal tissue counterparts. Thus, cancer cells may be more sensitive to ROS generation within the cells. Measurement of the cellular content of ROS after exposure to different concentrations of chloroformic extract of Celtis aetnensis (Tornab.) Strobl demostrated a significant dosedependent increase in the levels of ROS (Fig. 4).

These results suggest that in the Caco- 2 tumor cell line the chloroformic extract of Celtis aetnensis (Tornab.) Strobl acted as a pro-oxidant rather than as an antioxidant. These observations indicate that this extract may act indirectly and that its action may be mediated by other intracellular factors, likely targets of ROS.

These results are in agreement with other authors who demonstrated that phenolic compounds with high reducing ability may also act as pro-oxidants, thus generating ROS (39). The pro-oxidant activity of chloroformic extract of Celtis aetnensis (Tornab.) Strobl in Caco-2 cells was confirmed by results regarding thiol group determination; these endogenous antioxidants act concurrently by scavenging and/or reducing free radicals, breaking the peroxidative chain and thus allowing the repair of oxidatively damaged molecules (Fig. 5). The present study demonstrated that exposure of Caco 2 cells to a chloroformic extract of Celtis aetnensis (Tornab.) Strobl induced a significant dose-dependent decrease in RSH levels suggesting that the antioxidant system was not able to buffer the overproduction of ROS (Fig. 5). The intracellular decrease 
in RSH content appears to be a central event in Caco2 cell death induced by the chloroformic extract of Celtis aetnensis (Tornab.) Strobl. suggesting an interference of flavonoid and triterpenic compounds on the oxidant/antioxidant cell balance with consequent cell damage.

This study also evaluated the expression of HO-1, one of the most effective mechanisms for cellular protection against oxidative stress. The expression of HO-1 is increased by several types of cell stress including redox signals, heme, UV radiation, heavy metals, cytokines and $\operatorname{ROS}(40,41)$. The role of HO-1 in cancer biology is far from completely understood. In cancer, $\mathrm{HO}-1$ has been described as a pro-tumoral molecule due to its anti-apoptotic effects on colon cancer and hepatoma in murine models and its proangiogenic effects in human pancreatic cancer $(42,43)$. By contrast, in human tongue cancer, low HO-1 expression has been associated with an increased risk of developing lymph node metastasis (44).

In this study, we observed that the extract of Celtis aetnensis (Tornab.) Strobl decreased the expression of HO-1 (Fig. 6). Since HO-1 expression represents an important protective endogenous mechanism, its reduced expression, together with low RSH levels and high ROS production, may contribute to cell death.

To better understand the actions of the Celtis aetnensis (Tornab.) Strobl extract, we also evaluated $\gamma$-GCS expression, the rate-limiting enzyme in gluthatione synthesis, which can be considered as one of the major antioxidant enzymes.

A shown in Fig. 7 the expression of $\gamma$-GCS was not modified in the Celtis aetnensis-treated Caco-2 cells suggesting that lowered GSH levels, observed following extract treatment may be due to increase ROS generation rather than to inhibition of glutathione synthesis. Thus, the chloroformic extract of Celtis aetnensis (Tornab.) Strobl, inducing a decrease in antioxidant defenses, acts on Caco 2 cells which are susceptible to oxidative damage, as a potentially powerful promoter of oxidative processes.

It is reasonable to hypothesize that some of the compounds present in Celtis aetnensis (Tornab.) Strobl extract, which have been shown to afford considerable protection against cancer by inhibiting, for example, oxidative stress, may also exhibit anticancer effects. Thus, our study supports the growing body of data suggesting the bioactivities of Celtis aetnensis (Tornab.) Strobl and its potential impact on cancer therapy and on human health. Identification of natural chemopreventive compounds is urgently needed to help the further design and administration of preclinical and clinical trials.

\section{Acknowledgements}

The authors would like to thank Dr M. Wilkinson (Research Assistant) for proofreading the manuscript.

\section{References}

1. Moulton JE: Tumors of alimentary tract. In: Tumors in Domestic Animals. Moulton JE III (ed). University of California Press, Berkeley, pp240-272, 1977.

2. Jemal A, Bray F, Center MM, Ferlay J, Ward E and Forman D Worldwide variations in colorectal cancer. CA Cancer J Clin 61: 69-90, 2011.

3. Center MM, Jemal A, Smith RA and Ward E: Worldwide variations in colorectal cancer. CA Cancer J Clin 59: 366-378, 2009.
4. Fung TT and Brown LS: Dietary patterns and the risk of colorectal cancer. Curr Nutr Rep 2: 48-55, 2013.

5. Armstrong B and Doll R: Environmental factors and cancer incidence and mortality in different countries, with special reference to dietary practices. Int J Cancer 15: 617-631, 1975.

6 . Key TJ: Fruit and vegetables and cancer risk. Br J Cancer 104: 6-11, 2011.

7. World Cancer Research Fund and American Institute for Cancer Research:WCRF/AICR Systematic Literature Review Continuous Update Project Report: The Associations between Food. Nutrition and Physical Activity and the Risk of Colorectal Cancer, 2011. www.wcrf.org/int/research-we-fund/cancer-preventionrecommendations/pant-foods. Access date: June 2015.

8. Etkin NL: Medicinal cuisines: Diet and ethnopharmacology. Int J Pharmacogn 34: 313-326, 1996.

9. Lee JE: Vitamin D and colorectal cancer prevention: A review of epidemiologic studies. Curr Nutr Rep 2: 27-36, 2013.

10. Hwang BY, Chai HB, Kardono LBS, Riswan S, Farnsworth NR, Cordell GA, Pezzuto JM and Kinghorn AD: Cytotoxic triterpenes from the twigs of Celtis philippinensis. Phytochemistry 62: 197-201, 2003.

11. Pignatti S: Flora d'Italia. Edagricole, Bologna, p122, 1997.

12. Chari VM, Neelakantan S and Seshadri TR: Chemical components of Betula utilis and Celtis australis. Indian J Chem 6: 231-234, 1968.

13. Borges FFV, Machado TC, Cunha KS, Pereira KC, Costa EA, De Paula JR and Chen-Chen L: Assessment of the cytotoxic, genotoxic, and antigenotoxic activities of Celtis iguanaea (Jacq.) in mice. An Acad Bras Cienc 85: 955-964, 2013.

14. Santa-Cruz LH, Turner CE, Knapp JE, Schiff PL Jr and Slatkin DJ: Moretenol and other constituents of Celtis laevigata. Phy tochemistry 14: 2532-2533, 1975.

15. Adedapo AA, Jimoh FO, Afolayan AJ and Masika PJ: Antioxidant properties of the methanol extracts of the leaves and stems of Celtis africana. Rec Nat Prod 3: 23-31, 2009.

16. El-Alfy TS, El-Gohary HM, Sokkar NM, Hosny M and Al-Mahdy DA: A new flavonoid C-Glycoside from Celtis australis L. and Celtis occidentalis $\mathrm{L}$. leaves and potential antioxidant and cytotoxic activities. Sci Pharm 79: 963-975, 2011.

17. Weisburger JH: Antimutagenesis and anticarcinogenesis, from the past to the future. Mutat Res 480-481: 23-35, 2001.

18. Balkwill $\mathrm{F}$ and Mantovani A: Inflammation and cancer: Back to Virchow? Lancet 357: 539-545, 2001.

19. Ohshima H, Tatemichi M and Sawa T: Chemical basis of inflammation-induced carcinogenesis. Arch Biochem Biophys 417: 3-11, 2003.

20. Acquaviva R, Campisi A, Murabito P, Raciti G, Avola R, Mangiameli S, Musumeci I, Barcellona ML, Vanella A and Li Volti G: Propofol attenuates peroxynitrite-mediated DNA damage and apoptosis in cultured astrocytes: An alternative protective mechanism. Anesthesiology 101: 1363-1371, 2004.

21. Acquaviva R, Di Giacomo C, Sorrenti V, Galvano F, Santangelo R, Cardile V, Gangia S, D'Orazio N, Abraham NG and Vanella L: Antiproliferative effect of oleuropein in prostate cell lines. Int J Oncol 41: 31-38, 2012.

22. Di Giacomo C, Acquaviva R, Sorrenti V, Vanella A, Grasso S, Barcellona ML, Galvano F, Vanella L and Renis M: Oxidative and antioxidant status in plasma of runners: Effect of oral supplementation with natural antioxidants. J Med Food 12: 145-150, 2009.

23. Bradford MM: A rapid and sensitive method for the quantitation of microgram quantities of protein utilizing the principle of protein-dye binding. Anal Biochem 72: 248-254, 1976.

24. Russo A, Borrelli F, Campisi A, Acquaviva R, Raciti G and Vanella A: Nitric oxide-related toxicity in cultured astrocytes: Effect of Bacopa monniera. Life Sci 73: 1517-1526, 2003.

25. Li Volti G, Galvano F, Frigiola A, Guccione S, Di Giacomo C, Forte S, Tringali G, Caruso M, Adekoya OA and Gazzolo D: Potential immunoregulatory role of heme oxygenase- 1 in human milk: A combined biochemical and molecular modeling approach. J Nutr Biochem 21: 865-871, 2010.

26. Bastide $P$, Darido C, Pannequin J, Kist R, Robine S, Marty-Double C, Bibeau F, Scherer G, Joubert D, Hollande F, et al: Sox9 regulates cell proliferation and is required for Paneth cell differentiation in the intestinal epithelium. J Cell Biol 178: 635-648, 2007.

27. Panza A, Pazienza V, Ripoli M, Benegiamo G, Gentile A, Valvano MR, Augello B, Merla G, Prattichizzo C, Tavano F, et al: Interplay between SOX9, $\beta$-catenin and PPAR $\gamma$ activation in colorectal cancer. Biochim Biophys Acta 1833: 1853-1865, 2013. 
28. Fadeel B and Orrenius S: Apoptosis: A basic biological phenomenon with wide-ranging implications in human disease. J Intern Med 258: 479-517, 2005.

29. Tang WM, Chan E, Kwok CY, Lee YK, Wu JH, Wan CW, Chan RYK, Yu PHF and Chan SW: A review of the anticancer and immunomodulatory effects of Lycium barbarum fruit. Inflammopharmacology 20: 307-314, 2012.

30. Sarkar FH, Li Y, Wang Z and Kong D: Novel targets for prostate cancer chemoprevention. Endocr Relat Cancer 17: R195-R212, 2010.

31. Reyes FJ, Centelles JJ, Lupiáñez JA and Cascante $\mathbf{M}$ (2Alpha,3beta)-2,3-dihydroxyolean-12-en-28-oic acid, a new natural triterpene from Olea europea, induces caspase dependent apoptosis selectively in colon adenocarcinoma cells. FEBS Lett 580: 6302-6310, 2006.

32. Liu J: Pharmacology of oleanolic acid and ursolic acid. J Ethnopharmacol 49: 57-68, 1995.

33. Murakami S, Takashima H, Sato-Watanabe M, Chonan S, Yamamoto K, Saitoh M, Saito S, Yoshimura H, Sugawara K, Yang J, et al: Ursolic acid, an antagonist for transforming growth factor (TGF)-beta1. FEBS Lett 566: 55-59, 2004.

34. Valko M, Rhodes CJ, Moncol J, Izakovic M and Mazur M: Free radicals, metals and antioxidants in oxidative stress-induced cancer. Chem Biol Interact 160: 1-40, 2006.

35. Conner EM and Grisham MB: Inflammation, free radicals, and antioxidants. Nutrition 12: 274-277, 1996.

36. Wang SY and Jiao H: Scavenging capacity of berry crops on superoxide radicals, hydrogen peroxide, hydroxyl radicals, and singlet oxygen. J Agric Food Chem 48: 5677-5684, 2000.

37. Hirano T, Abe K, Gotoh M and Oka K: Citrus flavone tangeretin inhibits leukaemic HL-60 cell growth partially through induction of apoptosis with less cytotoxicity on normal lymphocytes. Br J Cancer 72: 1380-1388, 1995.
38. World Cancer Research Fund and American Institute for Cancer Research: Patterns of diet and cancer. In: Food, Nutrition and the Prevention of Cancer: A Global Perspective. American Institute for Cancer Research, Washington, DC, pp430-471, 1997.

39. Wlodek L and Steven HZ: Antioxidants, programmed cell death, and cancer. Nutr Res 21: 295-307, 2001.

40. Choi AM and Alam J: Heme oxygenase-1: Function, regulation, and implication of a novel stress-inducible protein in oxidant-induced lung injury. Am J Respir Cell Mol Biol 15: 9-19, 1996.

41. Camhi SL, Alam J, Wiegand GW, Chin BY and Choi AM: Transcriptional activation of the HO-1 gene by lipopolysaccharide is mediated by 5' distal enhancers: Role of reactive oxygen intermediates and AP-1. Am J Respir Cell Mol Biol 18: 226-234, 1998.

42. Sunamura M, Duda DG, Ghattas MH, Lozonschi L, Motoi F, Yamauchi J, Matsuno S, Shibahara S and Abraham NG: Heme oxygenase-1 accelerates tumor angiogenesis of human pancreatic cancer. Angiogenesis 6: 15-24, 2003.

43. Hill M, Pereira V, Chauveau C, Zagani R, Remy S, Tesson L, Mazal D, Ubillos L, Brion R, Asghar K, et al: Heme oxygenase-1 inhibits rat and human breast cancer cell proliferation: Mutual cross inhibition with indoleamine 2,3-dioxygenase. FASEB J 19: 1957-1968, 2005.

44. Yanagawa T, Omura K, Harada H, Nakaso K, Iwasa S, Koyama Y, Onizawa K, Yusa H and Yoshida H: Heme oxygenase-1 expression predicts cervical lymph node metastasis of tongue squamous cell carcinomas. Oral Oncol 40: 21-27, 2004. 